Articles 


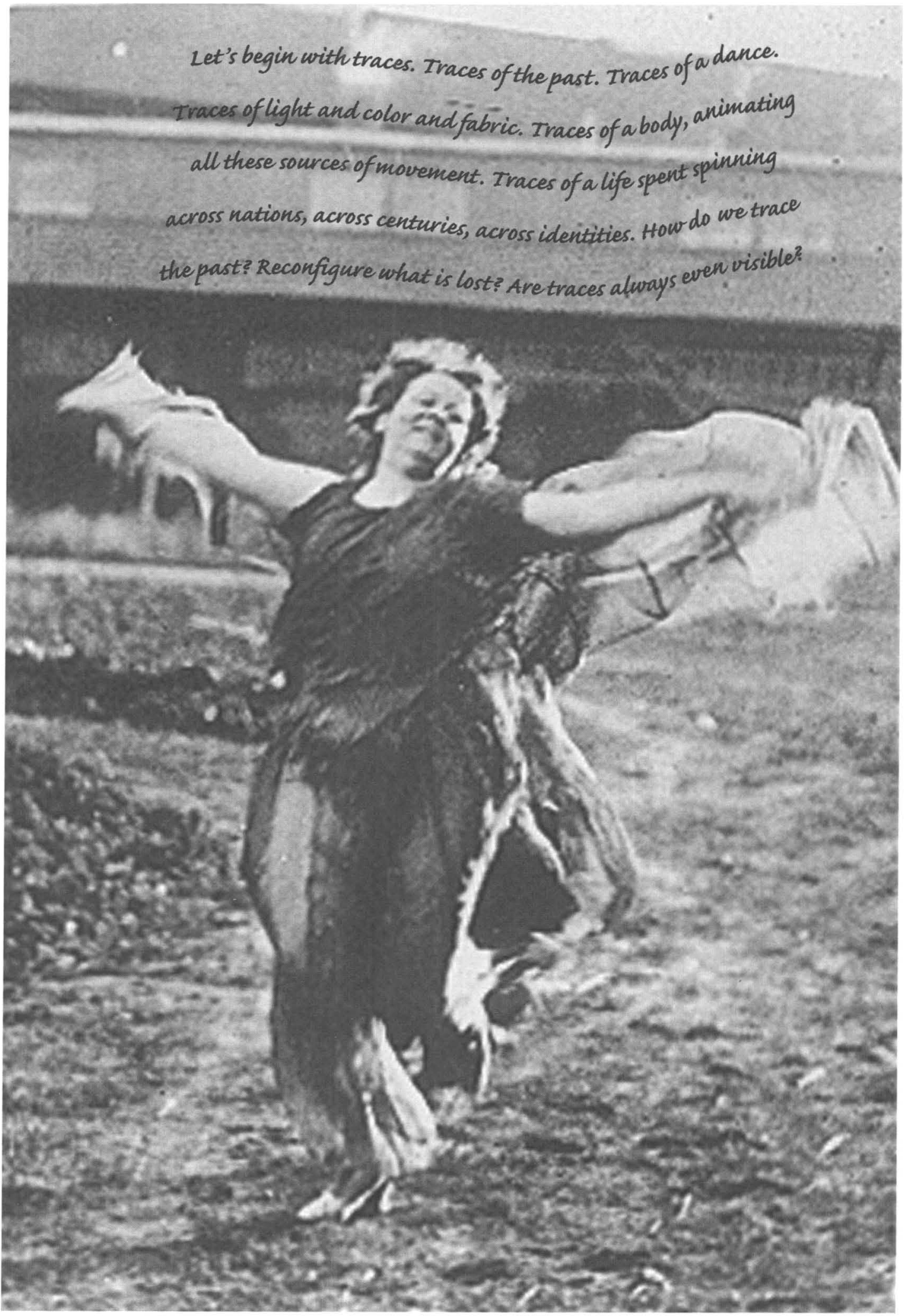

Loze Fuller (I9oo) Photograph by Eugene Druet. Courtesy of the Musée Rodın, Parts 


\title{
Matters of Tact: Writing History from the Inside Out
}

\author{
Ann Cooper Albright
}

ong before I became a committed academic, long before I was a college professor teaching dance history, long before terminal degrees and professional titles, I chanced upon an exhibition of early dance photographs at the Rodin Museum in Paris. I bought the small catalogue, and from time to time I would page through the striking black and white images searching for dancing inspiration. I always paused at a certain one of Loïe Fuller. There she is, radiant in the sunlight of Rodin's garden, chest open, arms spread like great wings, running full force towards the camera. It is an image of a strong, mature woman, one who exudes a joyful, yet earthy energy. A copy of this photograph taken in 1900 by Eugène Druet currently hangs above my desk.

With a nod to the meanings embedded in historical study, Walter Benjamin once wrote: "To dwell means to leave traces" $(1999,9)$. Indeed, traces are the material artifacts that constitute the stuff of historical inquiry, the bits and pieces of a life that scholars follow, gather up, and survey. The word itself suggests the actual imprint of a figure who has passed, the footprint, mark or impression of a person or event. These kinds of traces are omnipresent in the case of Loïe Fuller. Some traces are more visible than others, some more easily located. But all traces-once noticed-draw us into another reality. Someone passed this way before.

I had been thinking about writing a book on Loïe Fuller for some time, but it took me awhile to come to terms with how I wanted to respond to the less visible traces of her work. My book project began with a question: Why do so many critics and historians dismiss the bodily experience of her dancing in their discussions of Fuller's theatrical work? The question grew into a dance. The dance, in turn, taught me how to write history from inside the vibrations of its ongoing motion. This is the story of an intellectual ap-

A performer, choreographer, and feminist scholar, Ann Cooper Albright is an associate professor in the dance and theater program at Oberlin College. Combining her interests in dancing and cultural theory, she is involved in teaching a variety of dance, performance studies, and gender studies courses which seek to engage students in practices and theories of the body. She is the author of Cboreo- graphing Difference: The Body and Identity in Contemporary Dance, and co-editor of Moving History/Dancing Cultures and Taken By Surprise: Improvisation in Dance and Mind (all by Wesleyan University Press). In addition to making dances these days, she is currently working on a new book entitled Traces of Light: Absence and Presence in the Work of Lone Fuller. 
Perhaps we should lose the noun, which renders us nostalgic, maybe even melancholic at the extreme. Replace our ambition to find out what happened with a curiosity about how it came to be that it was happening. Replace traces with tracing - the past with the passion. Iracing the contours of fabric which spiral upward and outward, we spill over beyond any proach one historical or aesthetic discourse. This act of tracing can help us to the past that become aware not only of what's visible, but also what is, not only recognizes the corporeal effects of the historian's vantage point, but also mobilizes her body within the process of research and writing. This is the has been, will always be, less clearly visible. story of a dance shared across a century of time and two continents, a dance that takes place at the meeting point of physical empathy and historical difference.

I am engaged in writing on Loï Fuller. I use this term 'engaged' very consciously, for I want to highlight both the sense of binding oneself to another person and its etymological meaning as 'interlocking,' a literal as well as a figurative meshing with someone or something. I have chosen to work on this book in a way that integrates conceptual and somatic knowledges, engaging my physical as well as my intellectual and analytic facilities. Dancing amid clouds of fabric in elaborate lighting effects, I try to understand something of Fuller's experience from the inside out. I also dance with words, moving with my writing to see how ideas resonate in my body. Then too, as I weave my way through archival materials and historical accounts of cultural milieus, I practice staying attentive to what I have learned through that dancing experience. This research process challenges traditional separations between academic scholarship and artistic creation, between criticism and autobiography-in short, between dancing and writing. More than just another layer of historical excavation, my dancing creates a strand of physical thinking that weaves back and forth between the presence of historical artifacts (posters, reviews, photos, memoirs, and paintings) and the absence of Fuller's physical motion.

Trac

This essay is an attempt to articulate the theoretical implications of my ing the past - the rather quixotic methodology, an attempt to understand the very con-

past in light of the present. ditions of its possibilities. In what follows, I identify two strategies-two practices, if you will-that guide my

Present tense, the tension produced by the conjunction of light and dance - the subjunctive mode - the connection of her and me. She. Aware of my desire to trace history through choreography, to write with my body, I meet scholarship on Fuller. While one is primarily intellectual and the other is based in physical study, both practices refuse the conventional separation of scholaranother's dancing with my own. 


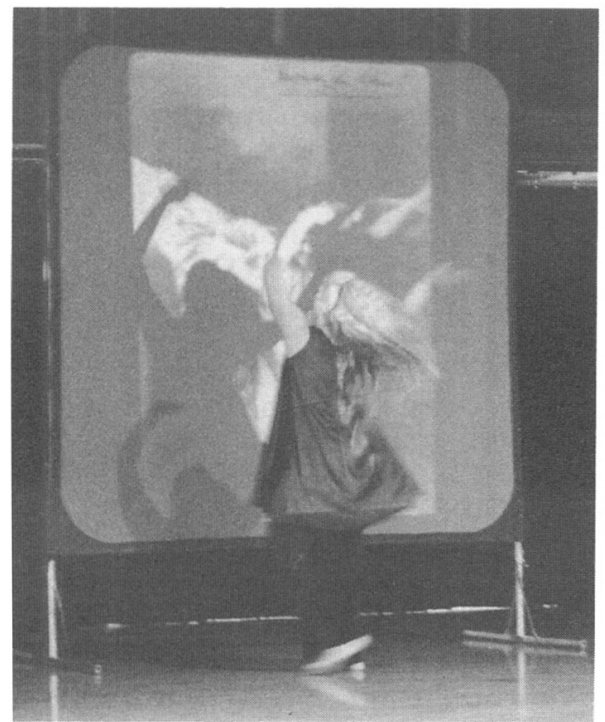

Ann Cooper Albright. Photograph by Cynthia Stewart. Courtesy of the photographer. ship and the studio, folding themselves into a mix of dancing and writing that houses physical receptiveness at its core. These strands of embodied study create a textured fabric in which aspects of Fuller's work are made visible through my body as well as my writing.

In all writing, a body is traced, is the tracing and the trace- is the letter, yet never the letter, a literality or rather a lettericity that is no longer legible. A body is what cannot be read in a writing. (Or one has to understand reading as something other than decipherment. Rather, as touching, as being touched. Writing, reading: matters of tact.) (Nancy 1994, 24)

Despite its linguistic unwieldiness (an effect, no doubt, of the difficulties of translation), this quotation from Jean-Luc Nancy's "Corpus" signals what is for me a profound difference in my current approach to historical work. Moving from traces to tracing incorporates the ning in this tactile, and thereby refuses the traditional separation of object from subject. Reaching across time and space to touch Fuller's dancing means that I allow myself, in turn, to be touched, for it vortex of historical is impossible to touch anything in a way that does not also implicate one's own body. (Ask any kid who has just been burned.) Touching, then, becomes the space of our interaction, a mutual engagement. As I touch Fuller through my historical same, but the periphery changes. My skin is the silk is research, both textual and physical, I am touched in return. the cloth which extends her dancing into light and my dancing in and among the folds of others. Did you get it? Skin is my change, rewrite the communication be cause in my time the core dynamic remains the representation and kinesthetic legibility, I read the exsilk, my way of dancing beyond myself and losing the dancer in the dance.

Contact. As the context changes, the contact changes, but the passion remains the same, for contact is the way I connect across, through, by way of, with, for and among her desires to know the other, to know god or love. This exchange powers me for it holds the passion, the weight, the grit and the friction that sent her whirling among clouds of fabric and sends me turning into the bodies of those around me. 


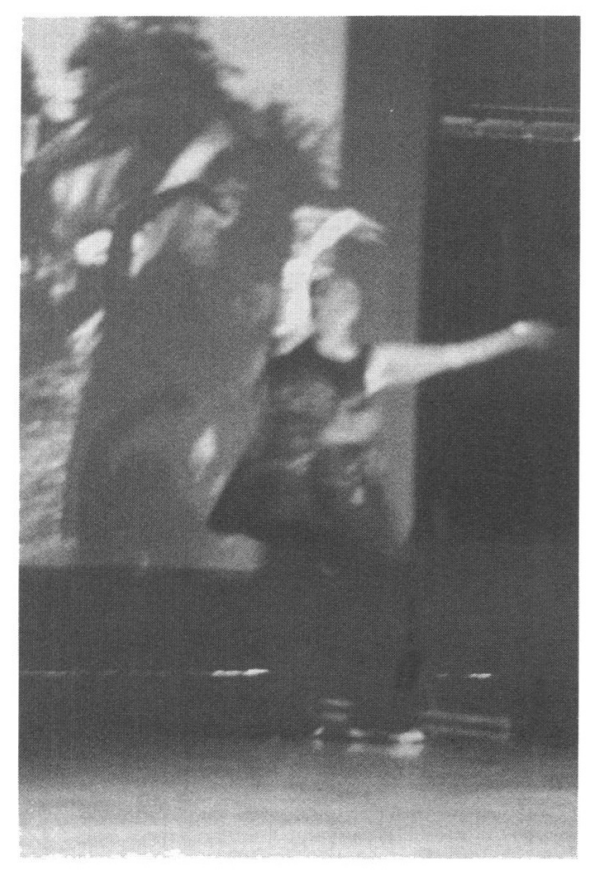

Ann Cooper Albright. Photograph by Cynthia Stewart. Courtesy of the photographer.
This metaphysical conundrum (How is one touched by history?) has, in my case, a very physical complement. Much of my dance experience over the past two decades has been generated by a form of contemporary dance called Contact Improvisation. In Contact, the actual point of contact-usually defined in terms of physical touching, although it can be rhythmic, visual, or kinesthetic - creates an improvisational space in which assumptions as to what the dance will be like (future tense) are eschewed in favor of a curiosity about what is happening now (present tense). The meeting point of Contact creates an interconnectedness of weight, momentum, and energy that channels a common physical destiny. The partnering in Contact is not simply an addition of one movement to another, but rather a realization that both movements will change in the midst of the improvisational duet. In addition to learning how to meet others in a dance, Contact dancers train in extreme spatial disorientation. Releasing the uprightness of the body and learning how to be comfortable upside down, rolling and spiraling in and out of the floor, falling without fear are all aspects of a training that redirects visual orientation into a kinesthetic grounding.

I think of the physical aspects of my research on Fuller in terms of a Contact duet. My body is influenced by her dancing as I imagine how she must have used her spine, her head, her chest. Spinning with my arms raised high and my head thrown back, historical descriptions of Fuller laid up in bed with excruciating pain and ice packs on her upper back make sense. Fuller must have slipped a disc in her cervical spine. These kinds of biographical details begin to make sense as I literally incorporate some aspects of the physical tolls her nightly performances must have incurred. Even on an intellectual or metaphysical level, I think of our interaction as a Contact duet, a somatic meeting set up by the traces of history. Envisioning this relation in terms of an improvisational duet usefully redefines the traditional separation of a historical subject (treated as the 'object' of study) and the omniscient writer of history. When, for instance, I review the enormous variety of images of "La Loie"-the posters, photographs, paintings, prints, and program covers - I try not only to analyze the visual representation of her work, but also to imagine the kind of dancing that inspired such visions. I allow myself to be touched (these "matters of tact") by what remains only partially visible.

In her introduction to Choreographing History, Susan Foster also sees the interaction of historian and the bodies of history as a dynamic tango between traces and tracing, artifacts and the language that reanimates their cultural significance. Her notion of "bodily theorics" engages with similar metaphors of writing history as a tactile duet, an improvisational connection between past and present bodies. But, she reminds us: 
This affiliation, based on a kind of kinesthetic empathy between living and dead but imagined bodies, enjoys no primal status outside the world of writing. It possesses no organic authority; it offers no ultimate validation for sentiment. But it is redolent with physical vitality and embraces a concern for beings that live and have lived. Once the historian's body recognizes value and meaning in kinesthesia, it cannot dis-animate the physical action of past bodies it has begun to sense. $(1995,7)$

Loie Fuller is one of the most interesting and paradoxical figures in early modern dance. Born in 1862 in Chicago, Fuller began performing in her teens, first as a temperance speaker and later as a member of the Buffalo Bill troupe, touring America on the vaudeville circuit. Her various

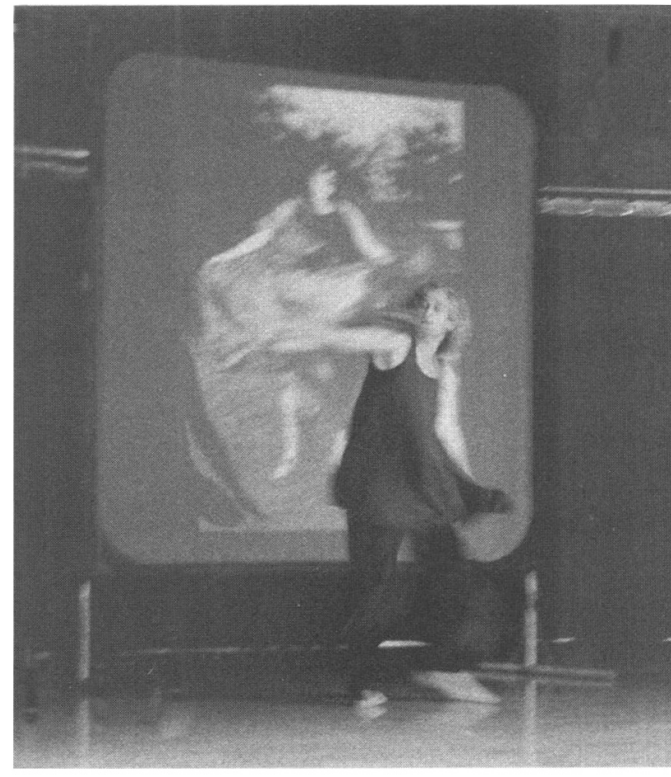

Ann Cooper Albright. Photograph by Cynthia Stewart. Courtesy of the photographer. dramatic roles included cross-dressed ones, such as the lead in the fast-paced melodrama Little Jack Sheppard, but it is as a Serpentine or skirt dancer that she became well-known. In the 1890 's, Fuller created an extraordinary sensation in Paris with her manipulations of hundreds of yards of silk, swirling high above her and lit dramatically from below. She embodied the fin-de-siècle images of woman as flower, woman as bird, woman as fire, woman as nature. One of the most famous dancers of her time, Fuller starred as the main act at the Folies Bergère, inspiring a host of contemporary fashions and imitators. Fuller's serpentine motif is also visible in much of the decorative imagery of Art Nouveau, and she was the subject of many works by renowned artists such as Rodin, Toulouse-Lautrec, and Mallarmé. Yet despite the importance of her artistic legacy, Fuller's theatrical work fits uneasily within the dominant narratives of early modern dance. Most historians don't see Fuller in light of the development of expressive movement, but rather relegate her to discussions concerning dance and lighting, or dance and technology.

Fuller's work embodies a central paradox of dance as a representation of both abstract movement and a physical body. Her dancing epitomizes the intriguing insubstantiality of movement caught in the process of tracing itself. Surrounded by a funnel of swirling fabric spiraling upwards into the space around her and bathed in colored lights of her own invention, Fuller's body seems to evaporate in the midst of her spectacle. Nonetheless, Fuller's body is undeniably present and discussions of her sartorial style and physical girth break through these romantic representations of her ethereality and femininity in interesting ways. Splayed across history and geography, Fuller's dancing takes place at the crossroads of diverse languages, two centuries, and many cultural changes. 


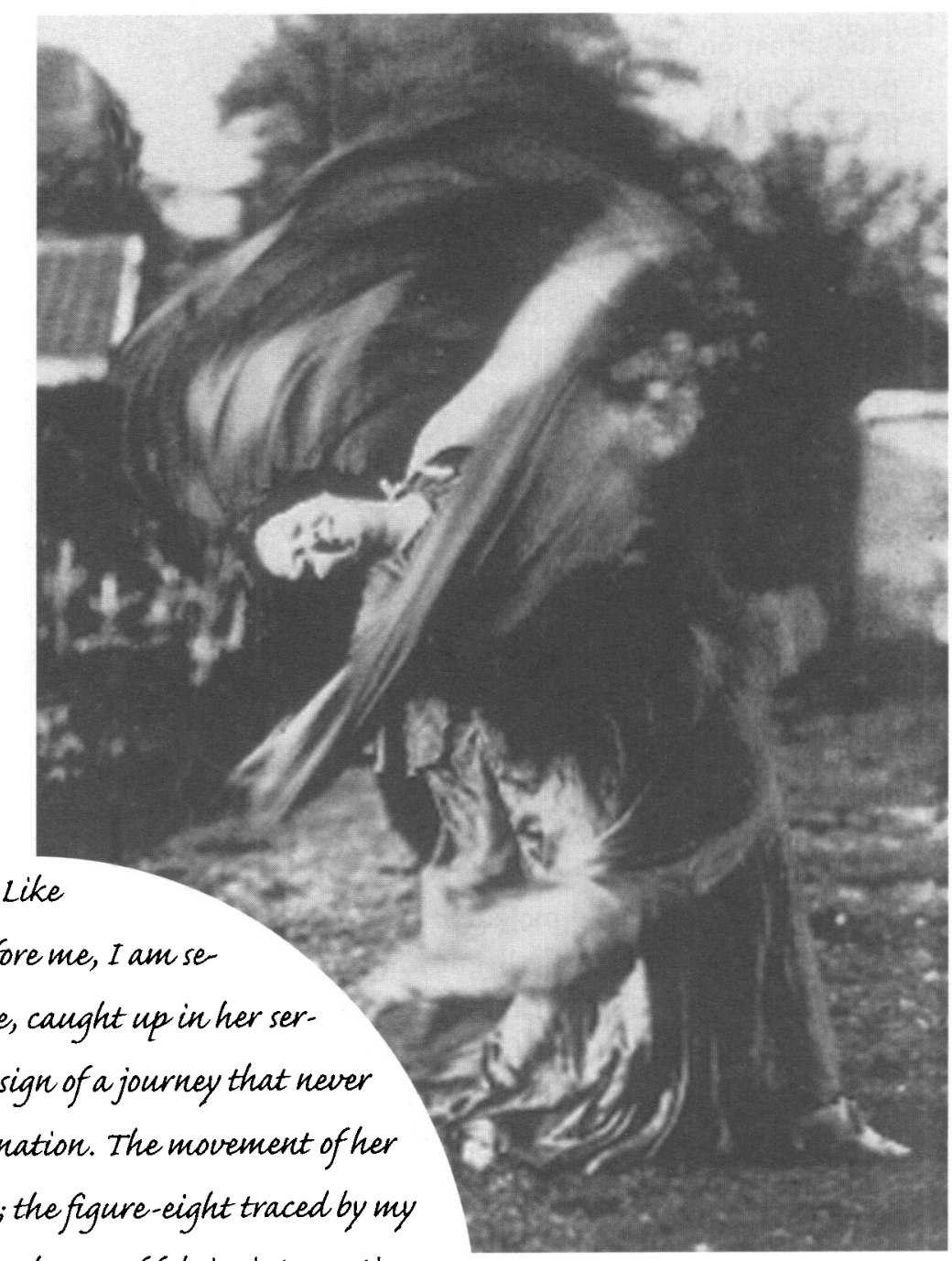

duced by the snake, caught up in her ser-

pentine motion. That sign of a journey that never ends, never finds a destination. The movement of her silks suspended in the air; the figure-eight traced by my arms as I spin beneath the shower of fabric, interpreting what my motion says about her history. Hungry to know more, to feel the power that generates her waves of motion, I study the place of this motif in Art Nouveau, read about late nineteenth-century Orientalism, dismiss as overly deterministic the lesbian reading of this figure as sexual insignia. I claim all of the above, none of the above.

Loïe Fuller dansant. Photograph by Eugène Druet. Courtesy of the Musée Rodin, Paris.

Intellectually, the material is fascinating. But there is something even more compelling for me in this subject. It's a gut thing. I feel that many scholars cover over the kinesthetic and material experience of her body in favor of the image, rather than reading that image as an extension of her dancing. Descriptions of her work get so entangled with artistic images or poetic renderings that they easily forget the physical labor involved. Then too, there are all those apologies and side notes 


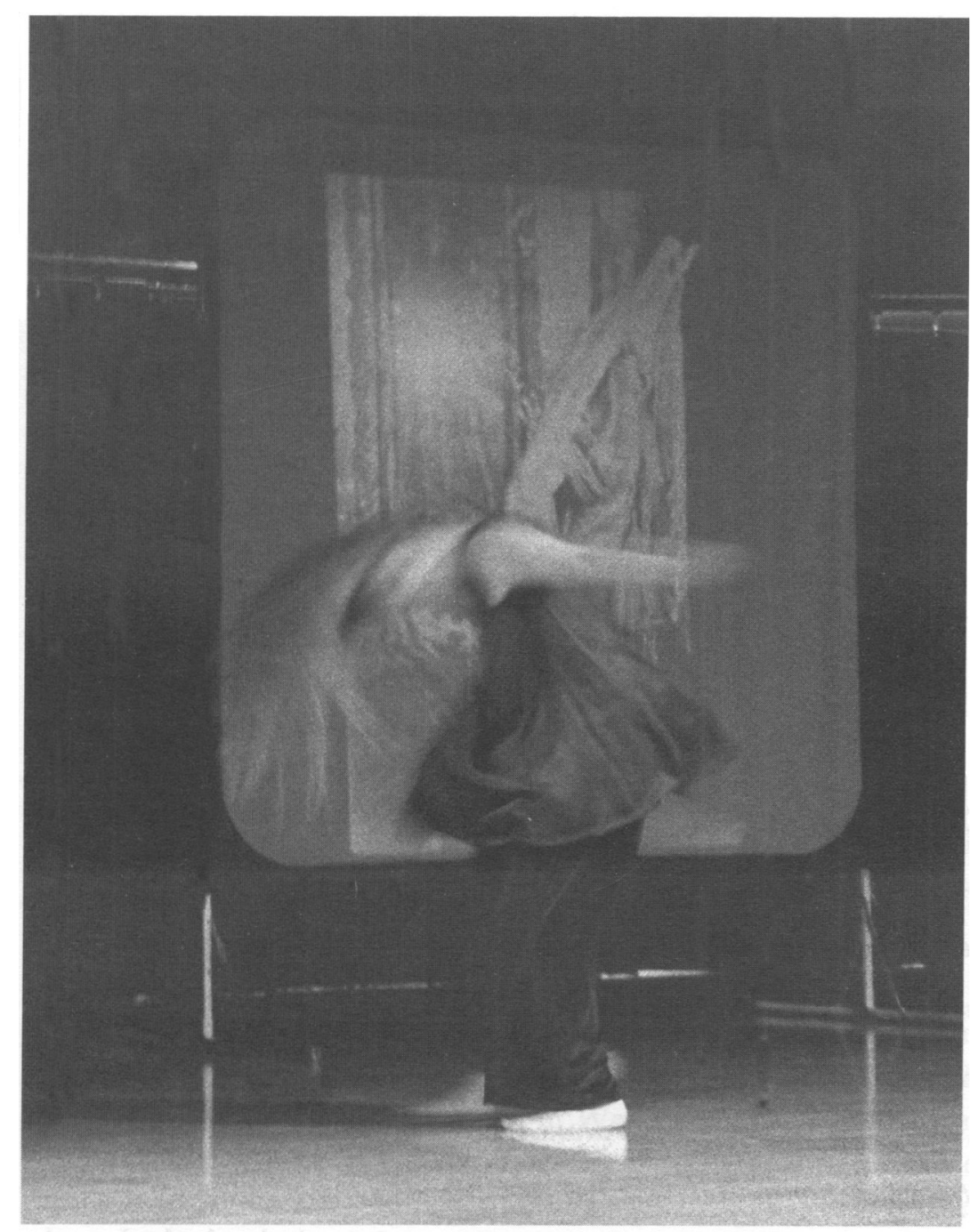

Ann Cooper Albright. Photograph by Cynthia Stewart. Courtesy of the photographer.

about how Fuller didn't have a dancer's body, or any dance training really, as if the movement images were solely dependent on the lighting, as if it were all technologically rendered. (One typical example: "The influence of Loie Fuller upon the theater will always be felt, particularly in the lighting of the scene and in the disposition of draperies. But she was never a great dancer. She was an apparition" [Flitch 1913, 88; emphasis added]. $)^{1}$ There is an odd urgency in my responses to these commentaries, my whole body revolts with the kinesthetic knowledge that something else was going on. Mybody tells me this.

Ten years ago, I made a dance called Traces of Light. It was the first time I incorporated light as a source of movement and stillness within the choreography. The first time I experienced what it was like to dance in, with, through, and next to light. The following year, I traced another dance that used light as a partner for movement. 
I recreated Fuller's Lily dance (1895), or, at least something approximating it. It was part of an evening-length choreography and although we meticulously reconstructed Fuller's patented design for costume and curved wands, I didn't think about this dance as a historical reconstruction, but rather as more of an interesting effect plundered from the abundant resources of early modern dance. Because of budget constraints, we used parachute material, not silk. Purple not white.

I remember the first time I danced in her costume. It felt odd to be cloaked in yards of fabric, me, who was so used to dancing in pants and a top with nothing in my way, every movement and each direction easily accessible. Within her costume, I have to prepare each step in order not to trip on the extra fabric. Twisting to one side, and then to the other, I gather my strength and then launch

$I$

was bitten by the spider. caught up in the tarantella; the pleasure of spinning, of turning continuously, sending waves of fabric higher. swirling and twisting. Spinning and running. If felt nauseous at first, my arms ached for weeks. Bitten by what used to be called the devil and what contemporary femi nists would reclaim as creative hysteria, I danced possessed, possessed by a body that was not mine and not, not mine. spinning in lights that dramatically shifted intensity, I lost my spatial bearings and felt history from another place. I knew very little about Lö̈e Euller, but I felt that somehow I understood quite a bit more. It was this bodily curiosity, this physical desire to understand her swirling from the inside out that motierated my decision many years later, to engage with this material, to dance with Lö̈e Fuller once again. the upper body strength and aerobic stamina Fuller must have had to keep the fabric aloft and swirling for upwards to forty-five minutes a night. How odd that some historians insist that she wasn't a dancer? Was it that she didn't look like a dancer? That she didn't act the way they thought a dancer should? Clearly she had a trained body and specific movement techniques in her body. In order to make a mere twelveminute solo with much less fabric than she used, I had to train intensively in my upper body for several months. In motion, my body talks back to historical representation and teaches me to look again, to read beyond the visual evidence and into its source. Ironically, then, where others savored the image of her disappearance (into the dark, into the folds of cloth, into the ideal symbol), I have come to appreciate the dynamic of her vital presence, those moments of becoming, and becoming again. 
In the ensuing decade, I would return to the costume and her dancing each time I taught early twentieth-century dance history. Taking history from the classroom to the studio, my students would try on Fuller's costume. But nothing happens until you begin to move and spin. Some students would get caught up in Fuller's whirl, the mystique of her dancing. Their enthusiasm inspired me. So did the increasingly sophisticated scholarly work being done on her by scholars such as Felicia McCarren, Rhonda Garelick, and Amy Koritz. Eventually, I became aware of a need to write on Fuller. Part physical, part intellectual, this desire was fueled by the intriguing complexities of a cultural moment in which a short, stocky lesbian from Chicago arrives in Paris to inspire a famous poet's evocation of the dancer as at once feminized and yet also decorporealized into a vision of pure movement.

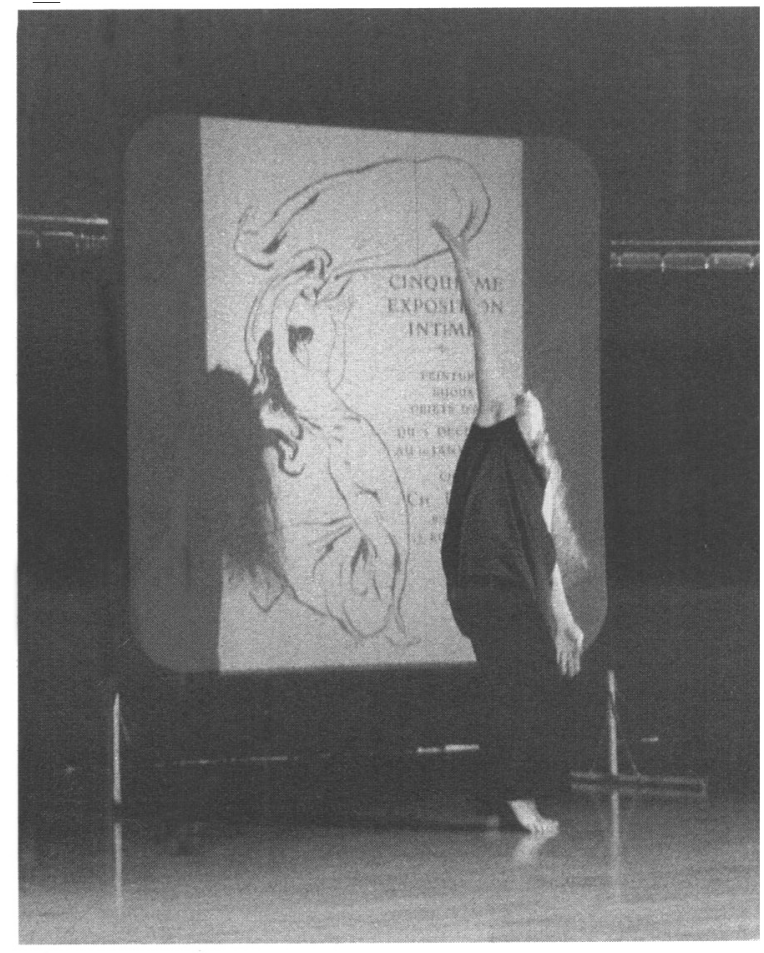

Ann Cooper Albright. Photograph by Cynthıa Stewart. Courtesy of the photographer.

What is so fascinating for me about dance as a historical phenomenon are the many different layers and kinds of information we need to excavate in order to understand that kinetic and artistic experience. What constitutes the dance as staged in Western theaters? Is it the movement? The dancers embodying the movement? The narrative plot or libretto? The entire theatrical apparatus including sets, costumes, music, choreographer, technicians, and company managers? The social and cultural context in which it was created? All of the above? In other words, what do we need in order to know the dancer and the dance?

In the introduction to their collection of essays, Acting on the Past, Mark Franko and Annette Richards describe this process of culling many different kinds of historical sources when they write: "Absent performative events have conceptual, imaginary, and evidential, as well as actively reproductive bases. They are especially characterized by movement between present and past, one in which archive and act, fragment and body, text and sounding, subject and practice, work in provocative interaction ..." $(2000,1)$.

I see my work as taking place in the midst of this "provocative interaction," right at the imaginative intersection of the past and the present. I visualize this (double) crossing spatially, marked in the center of a vast, cavernous space, much like the old wooden dance studio where I teach and work. At one end is the stage of the Folies Bergère. My view is from backstage, with all the workings of its magical effects revealed. Programs, posters, images of Loïe Fuller, as well as pages from her autobiography and countless 
other articles about her, dot the floor, creating a historical landscape and defining various pathways through the space. Improvising my way through these artifacts, I come to the opposite end where I also envision a backstage. This time, however, it is backstage of the theater where I work. There is a new plexiglass floor in the middle, underneath which we will project lights in multiple colors, reinventing Fuller's lighting designs within a contemporary context. It is the motion between these two backstage spaces (one in the past, one in the present) as well as the dancing pathways I construct from source to source that inform my research methodology.

As a major attraction in Paris at the end of the nineteenth century, Fuller left her mark on the imaginations of many poets and artists of her time. My scholar's cubicle in the library is filled with images of Fuller's dancing: posters, sculptures, photographs, articles about her. How do I respond to these traces? Looking at the reproductions, reading texts, I am fascinated - and moved. What would happen if I took these images, these ideas, into the studio? I grab my notebook and sprint out of the library. Inspired to move as well as to write, I take the plunge back into the physical, using my body as both a point of departure and as a moving vehicle, a method of transportation into history.

In an early essay entitled "Rereading as a Woman: The Body in Practice" feminist scholar Nancy Miller discusses the ways in which readings of literary texts are very much effected by the cultural experience of the reader. She writes: "To reread as a woman is at least to imagine the lady's place; to imagine while reading the place of a woman's body; to read reminded that her identity is also re-membered in stories of the body" $(1995,47)$. My studies in feminist theory, inspired by the work of scholars such as Nancy Miller, have taught me to be aware of how I produce a double reading-as a scholar, as a woman. These days I am challenging myself The to push the implications of Miller's essay even further, that is to say, to dance be read (and, by extension, to write) as a dancer, allowing my body to be present even in the midst of a scholarly project.

gins in a dim

light, a simple arm

gesture. Looking down

to my right, I scoop the space

next to me and reach up, as if

making an offering. Releasing the suspension with a breath, I twist behind

me to find another cone of light. This light in tensifies as I walk into its center. Surrounded by the

light, shrouded by the light, I can see it, feel it, touch it,

dance through it, but I cannot hold onto it.
Because I have decided to posit my dancing body as a resion, for my body certainly has a mind of its own and it doesn't always follow my instructions), I feel compelled to grapple with the relationship of my body to history. In the dance field, there often seems to be a split between researchers who focus primarily on reconstructing a dance from the past on bodies from the present, and those scholars who use dance as the hook into a broader cultural study of modes of production, representation, and reception of artistic endeavors. Now, 
of course, we all might quickly assert that we do both, but it is rare that I read an essay in which I feel that the writer's bodily knowledge was a crucial part of the scholarly process. Indeed, although theoretically we might be interested and excited by the possibilities of a dialogue between the dancing body of the researcher and that of the subject they are researching, we are rarely willing to confront that methodologically murky territory for ourselves. With this work on Fuller, I am asking what it would mean to research a historical body; a dancing body; a desiring body precisely through the intertext of an "other" body: my own. How can I use my embodied knowledge to move beyond the traces of artistic and literary representations of Fuller's dancing into the physicality at their core?

Over the past two years, I have developed a series of solo performances inspired by my work on Fuller. These dances take place at the intersection of historical research and choreographic expression. Although they do delineate a movement vocabulary that references Fuller's work, these choreographies are not reconstructions of her works. Spinning, spirals circling out of the upper body, and large expanAnn Cooper Albright. Photograph by John Seyfried. Courtesy of the photographer. sive gestures of the arms with an upward gaze of the face, these motifs constitute much of the dancing. My first solo, Searching for Loie, was a structured improvisation that used my earliest writings on Fuller as a sound score. Playing with the juxtaposition of poetic and expository prose, the read text created an open field (semi-serious, semi-playful) in which to explore my physical response to Fuller's historical legacy. Later, the dance morphed into a performative lecture entitled "Acts of Passion: Tracing History through Desire." In this more recent incarnation, I interrupt an academic discussion with dancing that pairs my movement with slide images of Fuller's dancing. Moving back and forth across the stage, my body interrupts the projections, flashing my shadow onto the screen. In these moments, Fuller's image is joined by my image, creating a complex duet involving interpretation, interconnection, and reflection. Bringing myself into the dancing in this manner forces me to reflect on my own intellectual position and physical experience, as I ask myself, "So what does this embodied experience tell me about history?" My answers to this question encompass both specific details as to her movement, staging and lighting techniques, as well as a more general sense of her performance energy and the role light played within Fuller's own personal cosmology.

Fuller thought of her theater spaces as laboratories in which to combine lights and movement in increasingly sophisticated ways. Fortunately, I have a wonderful collabo- 
rator and lighting designer who is also interested in Fuller's work and legacy. We were able, last year, to spend a significant amount of time experimenting with lighting in the theater. Our university situation gave us the luxury of time to create the lights and movement both simultaneously and interactively. Although we were not attempting to reconstruct her dances per se, we did use Fuller's original design patents and depictions of her staging (with live lighting technicians above, below and to the sides of her specially raised platform) to inform our updated use of her lighting inventions. For instance, we created a floor out of plexiglass, with intelligent lights revolving above and below its surface. The result was a twelve-minute performance entitled Dancing with Light.

Collaborating with a lighting designer for days on end, brought me closer, I believe, to the reality of Fuller's working environment. Not only did I begin to understand the physical labor involved, I understood why she is always pictured wearing shoes (the stage floors of variety theaters being notoriously dirty and riddled with nails and bits of this and that). I also realized that the reason she never mentions using haze to intensify the rays of light (an effect every critic comments on) was because the theaters were already so dusty and smoky, one didn't need any additional stuff in the air. It seems so simple and obvious, but the physical experience of making a dance in the middle of a busy theater jerked me out of the modern dance paradigm of solo artiste working alone in the studio waiting for inspiration, and brought me headlong into the gritty realities of popular theater. While it is true that at the beginning of her career, Loïe Fuller was most known as a soloist, she never performed anything without the committed assistance of a whole crew of technicians. Both an artist and a craftsperson in the theater, she transcended a deep and still omnipresent division between artistes and technicians, directors and staging hands, dancers and electricians.

For me, one of the most important aspects of Dancing with Light was a new appreciation of the experience of moving in strongly defined lights. Unlike lighting which has the sole purpose of illuminating the dancers, the lighting we created was an equal partner in the dance. Sometimes the light obscured me, sometimes it revealed my dancing, and sometimes I was simply a screen onto which a variety of moving lights were projected. At various times, I felt sheltered and enclosed, inspired, at times even disoriented (especially when dancing on clear glass with lights shining from underneath). The palpable presence of these lights reminded me of otherworldly spirits.

Returning to my study, I began to understand more concretely the spiritual role that light played for Fuller. I believe that she experienced a certain kind of euphoria when dancing that was intensified by her dramatic approach to lighting. Her dances generally followed a classic creation narrative. They began in a total blackout (which was highly unusual for that time), with the first strands of music calling forth a dim illumination of the small motions of her hands and fabric. The lights, movements, and music would generally crescendo into a final frenzy of color and motion which faded abruptly back into a primordial darkness. Fuller's published autobiography and unpublished letters and fragments of a book she was writing later in her life confirm the idea that for her, light had spiritual overtones. For instance, in an excerpt from a series of unpublished 
accounts of her life, Fuller describes the first moment she met Queen Marie of Romania, a woman with whom Fuller was to develop an intimate (albeit complicated) friendship. Under the sensationalized title of "The World Asks: the truth about Loïe Fuller and the Queen of Romania," Fuller writes:

There, coming toward me from the other end of a marvelous golden fairy-like room, was what appeared to be a spirit of light gliding along as if swept by the wind with the ends of its flowing garments, transparent in the sun that fell upon her as she approached . . . All was white, gold and blue around her. A smile such as I had never seen illuminated her countenance and permeated the atmosphere with joy and happiness. (n.d. folder 215, I5)

Clearly Fuller saw Marie as a saint-like figure, the physical embodiment of an enlightened being. Indeed, this is just one example of the many times Fuller uses light metaphors for spiritual goodness. I don't yet know what I will make of this visionary aspect of Fuller's work and life, but I do know that I would never have understood its significance without having danced in a light so defined I could pierce it with my body.

In her essay "The Concept of Intertextuality and Its Application in Dance Research," Janet Ashead-Lansdale identifies the imaginative possibilities of an approach to dance research that resonates with my own. She writes: "These methodological shifts of position are sometimes in harmony and often not, but they can be tolerated and made to function by seeing that it is in the spaces created between a multiplicity of texts and traces [that] there is the opportunity, indeed, more strongly, the demand, that each reader should engage in this process of constructing meaning by unraveling what seems to be implied by the work, or the method, or the discipline, while simultaneously creating their own threads from their own experience" (I999, III).

This layering of texts forms a web of signifying practices that merge and emerge depending upon the historical or methodological lens one chooses to use. Yet these intertexts can also produce a misleading sense that we have captured the thing itself, the presence of a dancing body. I want to introduce the concept of intertextuality, not in order to add simply another historical layer or methodological option, but rather to point out the space between these texts. While this space may figure as an absence, it is not necessarily a loss. Rather, I see it as a distance (both historical and cultural) across which desire always pulls interpretation. At once opportunity and demand (which I sometimes experience as an internal command, an urgency that compels action or speaks to a particular direction of thought), this intertextuality marks the space of improvisation possible within historical work. It recognizes the gap between myself and the subject of my inquiry - that historical distance-while simultaneously foregrounding the desire to close that gap, to build bridges and cross over from one period to another. Not every subject would necessarily elicit such mobile strategies. But given the elusive quality of Fuller's work and reception in combination with the unpredictable edge of my physical commitment to exploring her dances, this methodological fluidity seems right at the moment. 
I need to replace the act of history with an act of love - an act of rebellion against the pressure to separate in the name of academic integrity. Scholarly objectivity. Believe in the union, our unity, a trinity, with light casting its third shadow from there to here. Ripping through the conventions of textual analysis I enter the dance. She calls me, invites me to come, to penetrate the obvious with my kinesthetic imagination, to pierce her flesh with a language that writes its way into her body and mine, my mind mines hers, and mine too. Underneath her skin, I feel the rush of writing, the ecstasy of pouring my sweat, Writ- my blood, my need into her. Our juices blend, and blended they ing an academic book on whirl into an aquatic tornado of signification. You can't Fuller while making a series of dances incorporating aspects of her oeuvre opens up a capture water, but you can feel it - feel its force as intertextual space which can become the site of a negotiation between past and present bodies, between history and desire. More than a poststructuralist ploy (one in which movement is simply a slipit forces you to acknowledge the pressure, pery strategy of evasive criticism), however, this approach presses beyond the seams of traditional historical inquiry. Researching with my body brings me face to face (or body to body, so to speak) with my own physical predilections, intellectual interests, artistic agendas, and writerly desires. Certainly, I would never claim, as Giovanni Lista does in the introduction to his extensively researched book on Fuller that nothing is fictionalized, everything is "exact" fact. On the contrary, I have no desire to erase my voice within a critical project. I do, however, want to be self-conscious about my own connections to Fuller.

As I gaze once again at the photo above my desk (the one I described at the beginning of this essay), I understand one of the reasons why I find Loïe Fuller so compelling. Fuller was both a dancer and a lighting designer. This photo, along with so many other pieces of evidence (including the fact that she performed almost everyday for years, even when she could have easily substituted a younger dancer in her stead) confirms her deep need to dance. Yet she was most often seen not as a dancer, but rather as a "Magician of Light," to quote one biography. I, too, have a split identity, that of dancer and academic. Most people are more familiar with my writing than with my choreography. I point this out not to lament cultural prejudices about which bodies get represented as dancers (are you thin enough, young enough, non-verbal enough, etc.), but rather to highlight that my books, like Fuller's lighting, were composed from inside the vortex of motion. This co-motion fuels my interpretation as I trace the sources of her work. 
she. Me. We meet in a third space, a third mind provided by the light which stretches across time to warm my hands, to bake my heart, to infuse me with a desire to reach back, back into another world to find myself. The light comes from her smile, spirals out through my chest. Open, openhearted, I embrace her experience and I realize that this project is more than an academic exercise, more that a history book. I an writing about her, but I am writ. ing myself into her story.
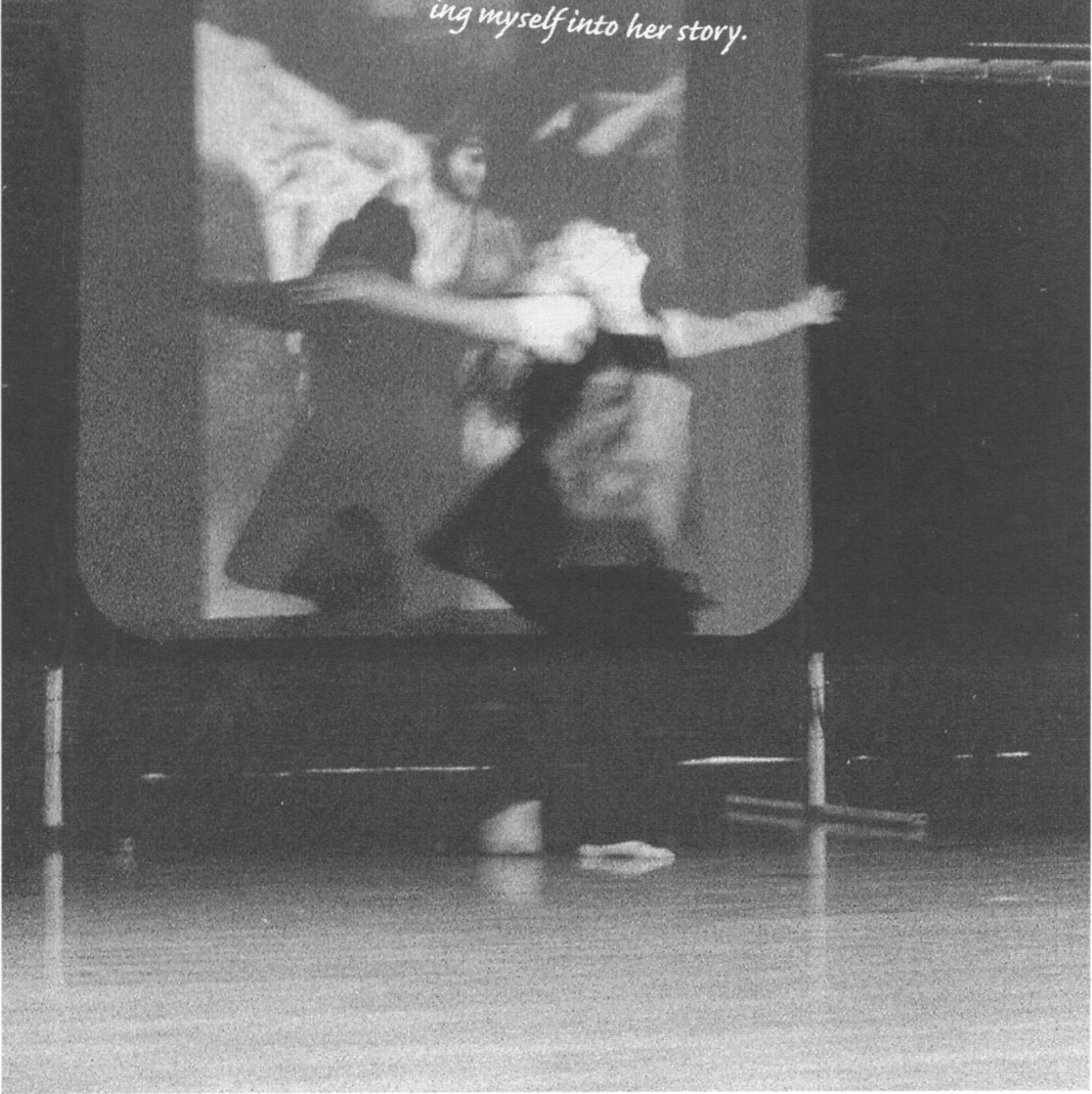

Ann Cooper Albright. Photograph by Cynthia Stewart. Courtesy of the photographer. 


\section{Notes}

I This is true of early writers such as Flitch (1913), as well as more recent work such as Ruchard Nelson Current and Marcia Ewing Current's Lote Fuller Goddess of Light (1997) and Giovanni Lista's Loue Fuller Danseuse de la Belle Époque (1994)

\section{Works Cited}

Ashead-Lansdale, Janet 1999 "The Concept of Intertextuality and Its Application in Dance Research "In Proceedings of the 2and Annual Conference, Soczety of Dance History Scholars 109-115

Benjamin, Walter 1999 The Arcades Project Cambridge, MA The Belnap Press of Harvard University Press

Current, Richard and Marcia Current 1997 Love Fuller Goddess of Light Boston Northeastern Unıversity Press

Flitch, J E Crawford I9I3 Modern Dancing and Dancers London Grant Richards, LTD

Foster, Susan 1995 "Choreographing History" In Choreographing History Edited by Susan Foster Bloomington Indiana University Press
Franko, Mark, and Annette Richards, eds 2000 Acting on the Past Hanover, NH Wesleyan University Press

Fuller, Loie nd "The World Asks the truth about Lore Fuller and the Queen of Romania" [unpublished manuscript] The Lote Fuller Collection Lincoln Center Dance Collection, New York Public Library, New York

Garelick, Rhonda K 1998 Ristng Star Dandyism, Gender, and Performance in the Fin de Siecle Princeton Princeton University Press

Lista, Giovannı 1994 Lore Fuller Danseuse de la Belle Époque Parıs Stock-Éditions d'art somogy

McCarren, Felıcia 1998 Dance Pathologies Performance, Poetzcs, Medicine Stanford Stanford University Press

Miller, Nancy 1995 "Rereading as a Woman The Body in Practice "In French Dressing, 45-52 New York and London Routledge Press

Nancy, Jean-Luc 1994 "Corpus" In Thinking Bodies Edited by Juliet Flower MacConnell and Laura Zakarm, I7-3I Stanford, CA Stanford University Press 